\title{
Amino acid digestibility and poultry feed formulation: expression, limitations and application
}

\author{
Wayne L. Bryden ${ }^{1}$, Xiuhua Li $^{1}$ \\ ${ }^{1}$ The University of Queensland, School of Animal Studies, Gatton QLD 4343 Australia.
}

ABSTRACT - The nutritional value or quality of dietary proteins used for poultry feed formulation varies: amino acid availability is an important measure of protein quality. Determination of ileal digestibility values has become the preferred method for estimating amino acid availability. This review discusses the different approaches to the expression of digestibility results, including correction for endogenous loss and the derivatisation of standardised values. Sources of variation in values include, the assay protocol, anti-nutritional factors in feedstuffs and feed milling. Feed formulating with ileal digestibility values should allow higher dietary inclusion levels of protein feedstuffs of lower quality provided that values of different feedstuffs are additive, the age of the bird and the use of feed enzymes are considered. An Australian data set of "ileal digestible amino acid values in feedstuffs for poultry" that has recently be published is described. This overview is intended to stimulate interest in the generation and application of ileal digestibility as a method for estimating amino acid availability in poultry nutrition.

Key Words: amino acids, apparent digestibility, chickens, endogenous loss, feedstuffs, ileum

\section{Digestibilidade de aminoácidos e formulação de rações para aves: expressão, limitações e aplicações}

\begin{abstract}
RESUMO - O valor nutritivo ou a qualidade das proteínas dietéticas utilizadas para a formulação de rações para aves varia: a disponibilidade de aminoácidos é uma medida importante da qualidade da proteína. A determinação dos valores de digestibilidade ileal tornou-se o método preferido para a estimativa da disponibilidade de aminoácidos. Nesta revisão são discutidas as diferentes abordagens para a expressão dos resultados de digestibilidade, incluindo a correção de perdas endógenas e a derivação de valores padronizados. As fontes de variação dos valores incluem o protocolo do ensaio, os fatores antinutricionais na alimentação e a indústria de alimentação. A formulação de rações com base nos valores de digestibilidade ileal deve permitir a inclusão de maiores níveis dietéticos de alimentos com proteína de qualidade inferior, desde que sejam considerados os valores dos diferentes alimentos aditivos, a idade da ave e o uso de enzimas para alimentação animal. Um conjunto de dados australianos de "valores de aminoácidos digestíveis ileais em alimentos para aves" acaba de ser publicado. Esta visão procura estimular o interesse na geração e aplicação de digestibilidade ileal como um método para estimativa da disponibilidade de aminoácidos na nutrição de aves.
\end{abstract}

Palvras-chave: alimentos, aminoácidos, digestibilidade aparente, galinhas, íleo, perda endógena

\section{Introduction}

Knowledge of the availability of amino acids in feedstuffs is an important feature of dietary protein quality. Reliable values of this feed ingredient attribute permit more efficient formulation of poultry diets. Many approaches have been made to determine amino acid availability (defined as that proportion of dietary amino acids that is in a form suitable for digestion, absorption and utilisation) using in vitro (enzymatic and chemical assays), indirect (microbiological or plasma amino acids) or direct (growth and digestibility assays) methods. The digestibility assay has become the most favoured technique for estimating availability, largely because the values apply directly to the bird and all amino acids can be measured in the one assay. Digestibility assays are applied assuming that the difference between input and output is a valid indicator of bioavailability and that digestion is likely to be the rate limiting step in amino acid availability. A number of excellent reviews have been published on digestibility assays (Sibbald, 1987; McNab, 1994; Ravindran \& Bryden, 1999a; Parsons, 2002; Lemme et al., 2004).

Two major areas of contention in digestibility assays are the use of ileal versus excreta collection procedures and correcting digestibility values for endogenous amino acid secretions. There have been few direct comparisons of ileal 
versus excreta digestibility methods but in a series of studies (Ravindran et al., 1999a) it was shown that there is greater variation in excreta values than there is in ileal values. Differences observed between ileal and excreta digestibilities in these studies clearly demonstrated that amino acid metabolism by hindgut microflora in chickens may be substantial and that digestibilities determined at the terminal ileum are a more accurate reflection of amino acid availability than those determined in excreta. Nevertheless, the excreta method using precision-fed roosters has been widely used in Canada, the United States and France and in the latter two countries the birds are caecetomised. In this procedure true amino acid digestibility is determined after correction for endogenous amino acid secretion into the gut (Parsons, 2002)

Internationally, however, there has been a growing consensus that the determination of amino acid digestibility in poultry should be based on the analysis of ileal digesta (Lemme et al., 2004; Ravindran et al., 2009). In this overview, the discussion will focus on aspects of the system of expression (apparent, true or standardised values), limitations due to variation and application of ileal digestibility values to the formulation of poultry diets.

\section{Amino acid digestibility systems}

A question often posed by commercial nutritionists concerns which digestible amino acid system is most appropriate for use in the formulation of poultry diets apparent or true digestibility values. Apparent digestibility measures the digestibility of amino acids of both dietary and endogenous origins. True digestibility, on the other hand, includes a correction for endogenous amino acid secretions. The relative merits of these two systems have been discussed in detail by Ravindran \& Bryden (1999a). It would appear that the choice of the appropriate system of digestible amino acids may depend on the method of formulating diets. If diets are being formulated to leastcost using linear programming, then apparent ileal digestibility values are the most appropriate as they take into account the endogenous cost of digestion. On the other hand, if diets are being formulated with computer simulation models, then true digestibility values will be relevant if the model corrects for the endogenous cost of digestion. It should be appreciated, however, that both digestible amino systems are superior to the total amino acid system and that all systems have specific applications and shortcomings.

Debate will continue regarding the need to correct amino acid digestibility values for endogenous loses and has been discussed comprehensively (Ravindran \& Bryden., 1999a; Parsons., 2002; Lemme et al., 2004). The measurement (see below) and correction of apparent digestibility for endogenous losses can introduce artefacts and mask important differences between feed ingredients. Although digestibility is often considered to be a characteristic of a diet or feed ingredient, it is, in reality, the property of the ingredient in relation to the animal to which the diet is given (McNab, 1994). It may be argued that if a feed ingredient increases endogenous amino acid flow out of the small intestine, that represents a loss to the animal and must be realistically 'charged' against the feed ingredient as lowered amino acid digestibility. However, it is now recognised that endogenous amino acid losses are influenced primarily by dry matter intake and secondarily by the inherent composition of the feed ingredient or diet (ie. fibre level, presence of anti-nutritional factors etc). These two fractions are referred to as basal (or non-specific) and specific endogenous amino acid losses, respectively as detailed by Stein et al. (2007).

The limitations of apparent ileal digestibility values could be overcome by standardising these estimates through corrections for basal endogenous losses, as suggested by Boisen (1998), Rademacher et al. (1999) and Lemme et al. (2004). The basal endogenous amino acid loss is defined as the minimal loss of endogenous amino acids. As noted above, the basal loss is proportional to dry matter intake and is independant of the composition of the ingredient or diet. The obvious advantage of this system is that apparent digestibility and basal endogenous losses need not be determined in the same experiment and standardised ileal digestibility values can be calculated for published apparent digestibility values. However, the question remains as to which method should be used to determine basal endogenous loss. Databases on standardised ileal digestibility values of amino acids in feed ingredients are now available, wherein published apparent digestibility values have been transformed to standardised values using existing literature data on endogenous amino acid recovery in ileal digesta (Lemme et al., 2004).

\section{Variation in ileal digestibility values}

A number of factors influence amino acid digestibility. The nature and digestion of dietary protein will reflect plant breeding programs, agronomic conditions, anti-nutritive factors and processing. Variation in digestibility values will also arise from difficulties associated with the conduct of assay procedures and the measurement of endogenous amino acid losses. Surprisingly, there are few instances in the literature where the significance of many of these sources of variation has been systematically evaluated. 


\section{Bioassay protocol and measurement of endogenous loss}

There are now a number of reference sources of known digestibility values for a range of feedstuffs. However, there is great confusion when one examines these compilations to know how to compare the values obtained by different procedures. Values have been derived using a number of different assay procedures that vary in terms of the age of the birds used, the collection site of digesta, feeding procedures, basal diet, dietary inclusion level of test ingredients, etc (Ravindran \& Bryden, 1999a) which all add to the uncertainty of the values obtained. There is a need for a universal approach to the measurement of ileal digestibility and for this to be achieved, agreement on; (i) assay diets, (ii) indigestible marker, (iii) age of birds, (iv) method of euthanasia, (v) site of digesta collection, (vi) method of digesta collection and (vii) processing of digesta, is required (Ravindran et al., 2009). Difficulties associated with amino acid analysis can also be a major source of variation which is often overlooked (Ravindran \& Bryden, 1999a). Moreover, the application of rapid techniques such as NIRS is dependent on the reliability of chemical analysis of amino acids.

With the increased application of standardised ileal digestibility values, it is important to appreciate that there are different approaches to the estimation of endogenous amino acid loss. Including a correction for endogenous amino acids should provide a more accurate value for comparing different diets or protein sources. Approaches to the estimation of endogenous amino acid loss in poultry have included the measurement of amino acids in excreta either during starvation, when fed a protein free diet, or by determining endogenous output at zero intake by regression analysis. However, the use of these practices, especially the first two, is intrinsically unsound because starvation or the absence of a nutrient, such as protein, profoundly alters metabolism and the bird can no longer be regarded as physiologically normal. Starvation or feeding a protein free diet are the methods used for endogenous correction in the precision-fed rooster excreta digestibility assay. We have used both the protein free diet and the regression analysis method to measure the entry of endogenous amino acids into the lower ileum of broilers and roosters and have shown that the two methods give different results that vary with the maturity of the bird. We have compared these techniques to the homoarginine method and have shown that both techniques significantly underestimate endogenous amino acid secretion when compared with the latter technique (Siriwan et al., 1994).
Bryden et al. (1996) and Ravindran \& Bryden (1999a) have discussed in detail the assumptions that are used when applying the homoarginine technique and these assumptions have been shown to be valid when tested. Interestingly, the values obtained by the homoarginine technique have been reported to be of similar magnitude to those measured using isotope dilution (Roos et al., 1994). Moughan et al. (1990) introduced the peptide alimentation method, in which birds are fed a semi-synthetic diet containing enzyme-hydrolysed casein (EHC) as the sole source of nitrogen. Endogenous amino acid values calculated using the EHC method are similar to those determined with the homoarginine method (Ravindran et al., 2004). These techniques have the advantage that they measure endogenous amino acids in birds that can be considered physiologically normal.

\section{Protein digestion and anti-nutritive factors}

All dietary sources of protein are heterogeneous mixtures of different proteins. It would be anticipated, therefore, that different proteins would be digested at different rates and this in turn would cause a variation in the rate at which different amino acids were taken up from the gut. However, the situation is more complex than this as proteins, although different in their chemical compositions, are not isolated entities but have various linkages with carbohydrate, lipids and other proteins so that these interactions and the composition of the diet may affect the digestibility of dietary protein (Hughes \& Choct, 1999).

In addition, digestion and absorption may be impaired by the presence of anti-nutritive factors in the diet. Protease inhibitors, lectins, polyphenolic compounds, saponins, nonstarch polysaccharides and phytate are examples of antinutritive factors that depress protein digestion and utilisation (Bryden, 1996; Hughes \& Choct, 1999). It has been known for some time that the major influence of antinutritive factors on protein nutrition has been a reduction in apparent protein digestibility. However, advances in the measurement of endogenous amino acids has allowed separation of the effects of reduced digestion of both exogenous and endogenous protein and increased endogenous secretion (Angkanaporn et al., 1994). Both factors would reduce apparent digestibility. The relative importance of these two avenues of amino acid loss by the bird will vary with different anti-nutritive factors (Bryden, 1996). The application of feed enzymes to poultry diets has also demonstrated the impact of anti-nutritive factors on apparent amino acid digestibility (see below). In a series of studies we have shown that the application of xylanase and phytase alone and in combination improves amino acid 
digestibility by amounts which can be quite significant in terms of overall feed formulation (Hew et al., 1998; Ravindran et al., 1999a,b; Hew et al., 1999; Ravindran et al., 2000, 2001; Selle et al., 2000; Selle et al., 2003a,b). The positive effect of enzymes on amino acid digestibility again demonstrates the impact of anti-nutritive factors on either reducing protein digestion and/or increasing endogenous amino acid loss. The net result is a decrease in apparent amino acid digestibility.

\section{Feed milling and feed enzymes}

Ironically, those feedstuffs (grain legumes, oil seed meals) which are used extensively as sources of dietary protein also contain the highest concentrations of antinutritional factors. For example, soyabean meal contains a range of anti-nutritional factors, many of which are heat labile and destroyed during feedstuff manufacture (Dale, 1996). In addition to feed milling or processing the most recent approach to combat the deleterious effects antinutritional factors is supplementing diets with feed enzymes that use these factors as substrate.

Heat treatment, essential for inactivation of many antinutrients, may reduce protein quality in the presence of carbohydrates by Maillard type reactions, protein crosslinking and amino acid racemisation (Friedman, 1996). Processing, especially heat treatment, may contribute to the variability of ingredients such as protein meals and cotton seed meal (Dale, 1996). Lysine is heat sensitive and the low digestibility of lysine in cotton seed meal may reflect heat processing of the meal. The variations in digestibilities of amino acids in meat meals are likely to be due to differences in raw ingredients, time between slaughter and rendering and the duration and temperature of the rendering process (Skurray, 1974). Obviously, optimum processing conditions for all protein meals that do not reduce amino acid digestibilities need to be established. Another aspect of processing, grinding, modifies particle size and shape without causing chemical changes in feedstuffs. It has been shown that grinding improves nutrient digestibility in birds (Hamilton \& Proudfoot, 1995). This may reflect the increased surface area available for enzyme attack during digestion (Amerah et al., 2007).

The use of feed enzymes and the application of digestible amino acid values have been the two most significant advances in feed production during the last two decades. Enzymes are added to diets to enable the bird to degrade anti-nutrient feed components (see above), in particular, non-starch polysaccharides and phytate. It has also been demonstrated that addition of feed enzymes improves amino acid digestibility and the metabolisable energy value of the diet. We have recently shown that both of these attributes of sorghum can be improved by the dietary addition of xylanase, phytase and protease (Table 1) which should overcome the inferior performance of starter broilers fed sorghum based diets (Bryden et al, 2009b; Selle et al., 2010).

The response to feed enzymes varies with diet composition (Table 2) and also depends on source and level of enzyme addition, and may reflect improved dietary protein digestion per se and/or a reduction in endogenous amino acid losses. For a detailed discussion of this aspect of ileal amino acid digestion, the reader is referred to number of comprehensive reviews, including Selle et al. (2000, 2006), Selle \& Ravindran (2007), Bryden et al. (2007), Cowieson \& Bedford (2009) and Cowieson et al. (2009).

\section{Application of digestibility values}

During the last two decades a significant number of digestibility values for feedstuffs used in poultry diets have been generated in laboratories around the world. When these values are evaluated (Li et al., 2002a) bird performance is superior to birds fed diets based on total digestible amino acid values (Table 3 ). Nevertheless, with the application of these values to feed formulation a number of issues need to be considered, including protein meals available, age of bird being fed and additivity of digestibility values.

\section{Low quality protein meals}

A major advantage of using digestible amino acids in diet formulation is that it makes it possible to increase the inclusion levels of alternate ingredients (in particular, low quality protein sources) in poultry diets. In effect, it will

Table 1 - Effect of dietary enzymes on AME and apparent ileal protein digestibility of sorghum in broilers (Sultan et al., 2010)

\begin{tabular}{lcc}
\hline Treatment & $\begin{array}{c}\text { Ileal protein } \\
\text { digestibility coefficient }\end{array}$ & $\begin{array}{c}\text { AME } \\
(\mathrm{MJ} / \mathrm{kg} \mathrm{DM})\end{array}$ \\
\hline Control & $0.78 \mathrm{bc}$ & $14.07 \mathrm{e}$ \\
Xylanase & $0.77 \mathrm{c}$ & $14.37 \mathrm{~d}$ \\
Phytase & $0.81 \mathrm{ab}$ & $14.62 \mathrm{c}$ \\
Protease & $0.82 \mathrm{a}$ & $14.81 \mathrm{bc}$ \\
Xylanase + Phytase & $0.81 \mathrm{abc}$ & $14.75 \mathrm{c}$ \\
Xylanase + Protease & $0.80 \mathrm{abc}$ & $14.66 \mathrm{c}$ \\
Phytase + Protease & $0.83 \mathrm{a}$ & $14.99 \mathrm{ab}$ \\
Xylanase + Phytase + & $0.81 \mathrm{ab}$ & $15.18 \mathrm{a}$ \\
Protease & & 0.06 \\
SEM & 0.01 &
\end{tabular}

abcde Values in the same row with different superscripts differ significantly $(\mathrm{P}<0.05)$. 
Table 2 - Effect of xylanase and phytase on the average apparent ileal digestibility coefficients of amino acids in different feed ingredients (Bryden \& Li, 2002)

\begin{tabular}{lcccc}
\hline Ingredient & Control & Xylanase & Phytase & Xylanase+ Phytase \\
\hline Wheat & $0.72 \mathrm{c}$ & $0.79 \mathrm{a}$ & $0.75 \mathrm{bc}$ & $0.77 \mathrm{ab}$ \\
Soyabean meal & 0.86 & 0.84 & 0.86 & 0.84 \\
Canola meal & $0.72 \mathrm{~b}$ & $0.74 \mathrm{~b}$ & $0.76 \mathrm{a}$ & 0.010 \\
Cottonseed meal & 0.73 & 0.73 & 0.74 & $0.74 \mathrm{ab}$ \\
Lupins & $0.82 \mathrm{a}$ & $0.77 \mathrm{~b}$ & $0.82 \mathrm{ab}$ & 0.09 \\
\hline
\end{tabular}

abcMeans in the same row with different superscripts differ significantly $(\mathrm{P}<0.05)$.

Table 3 - The performance of birds to day 42 when fed diets formulated on the basis of total (Diet 1), published (Ravindran et al., 1998a) (Diet 2) and determined (Diet 3) ileal digestible amino acid values (Li et al., 2002a)

\begin{tabular}{|c|c|c|c|c|}
\hline Parameter & Diet 1 & Diet 2 & Diet 3 & SEM \\
\hline $\begin{array}{l}\text { Body weight } \\
\text { gain (g/bird) }\end{array}$ & 1999b & $2325 a$ & $2345 a$ & 58.21 \\
\hline Feed intake (g/bird) & $3800 \mathrm{~b}$ & $4323 a$ & $4281 \mathrm{a}$ & 71.88 \\
\hline Feed conversion (g/g) & $1.89 \mathrm{a}$ & $1.83 b$ & $1.80 \mathrm{~b}$ & 0.17 \\
\hline $\begin{array}{l}\text { Breast muscle } \\
\text { (\% body weight) }\end{array}$ & $12.17 b$ & $15.43 a$ & $15.58 \mathrm{a}$ & 0.424 \\
\hline $\begin{array}{l}\text { Abdominal fat } \\
\text { pad (\% bodyweight) }\end{array}$ & $2.46 a$ & $2.00 \mathrm{~b}$ & $1.98 \mathrm{~b}$ & 0.032 \\
\hline
\end{tabular}

increase the range of ingredients that can be incorporated, improve the precision of formulation and ensure more predictable bird performance. In a series of studies evaluating canola meal (Ravindran et al., 1998b; Li et al., 2002b), cottonseed meal (Ravindran \& Bryden, 1999b; Li et al., 2002c) and meat and bone meal (Ravindran \& Bryden, 1999c; Ravindran et al., 2002), the beneficial effects of using apparent ileal digestible amino acids in broiler diet formulations to increase the inclusion levels of poorly digestible ingredients were demonstrated. In these studies, as expected, increasing dietary levels of canola meal, cottonseed meal and meat and bone meal on a total amino acid basis significantly lowered weight gains and feed efficiency of broilers. The observed depressions were, however, largely overcome when the diets were balanced on a digestible amino acid basis. This is in accord with previous studies on cottonseed meal (Fernandez \& Parsons, 1995) and several by-product ingredients (Rostagno et al., 1995; Douglas \& Parsons, 1999). These results confirm that the inclusion levels of poor quality protein sources in broiler diets can be increased when they are based on amino acid digestibility values without loss of bird performance (Table 4).
Table 4 - Effect of inclusion of different dietary levels of cottonseed meal on either a total (TAA) or ileal digestibility (DAA) basis on broiler performance from day 3 to 17 post-hatching (Bryden \& Li, 2002c)

\begin{tabular}{lcccc}
\hline $\begin{array}{l}\text { Cottonseed } \\
\text { meal }(\mathrm{g} / \mathrm{kg})\end{array}$ & $\begin{array}{c}\text { Formulation } \\
(\mathrm{g} / \mathrm{b})\end{array}$ & $\begin{array}{c}\text { Growth } \\
(\mathrm{g} / \mathrm{b} / \mathrm{d})\end{array}$ & Intake & g feed/g \\
\hline 0 & T AA & $472 \mathrm{c}$ & $48.1 \mathrm{~b}$ & $1.43 \mathrm{bc}$ \\
& DAA & $515 \mathrm{ab}$ & $50.5 \mathrm{ab}$ & $1.38 \mathrm{~d}$ \\
100 & TAA & $498 \mathrm{abc}$ & $49.5 \mathrm{~b}$ & $1.40 \mathrm{~cd}$ \\
& DAA & $516 \mathrm{a}$ & $50.9 \mathrm{ab}$ & $1.38 \mathrm{~d}$ \\
150 & TAA & $483 \mathrm{c}$ & $49.7 \mathrm{ab}$ & $1.44 \mathrm{~b}$ \\
& DAA & $516 \mathrm{a}$ & $52.7 \mathrm{a}$ & $1.43 \mathrm{bc}$ \\
300 & TAA & $338 \mathrm{~d}$ & $36.6 \mathrm{c}$ & $1.62 \mathrm{a}$ \\
& DAA & $488 \mathrm{bc}$ & $49.1 \mathrm{~b}$ & $1.42 \mathrm{bcd}$ \\
SEM & & 9.79 & 1.161 & 0.013 \\
LSD0.05 & & 27.268 & 3.319 & 0.044 \\
P value & & $<0.0001$ & $<0.0001$ & $<0.0001$ \\
\hline
\end{tabular}

a,b,c,d Values in the same row with different superscripts differ significantly $(\mathrm{P}<0.05)$.

\section{Age and physiological state of bird}

The ability of poultry to digest and absorb dietary protein is known to be influenced by age and physiological state. A concern often raised by commercial nutritionists is the relevance of digestibility values generated with birds of one age (ie. 42 days) to week-old chicks or laying hens. A number of studies have examined this factor using broilers of different ages, laying hens and roosters fed different cereals and protein meals (Wallis \& Balnave, 1984; Rostagno et al., 1995; Batal \& Parsons, 2002; Huang et al., 2005, 2006, 2007; Garcia et al., 2007). In general, the digestibility coefficients of amino acids increased with age and varied with feedstuff. The differences may in part, reflect differences in endogenous amino acid flows (Ravindran \& Hendriks, 2004).

The practice of using amino acid digestibility values generated with birds of one age to formulate diets for birds of a younger age or different physiological state should be undertaken with due regard to possible differences. Moreover, there is also the question that digestibility measured with adults may not reflect digestibility in the rapidly growing broiler chicken, which changes with age (Table 5). 
Table 5 - Effect of the age of broiler chickens on the average apparent ileal digestibility coefficients of different feed ingredients (Bryden \& Li, 2002)

\begin{tabular}{llll}
\hline & $14 \mathrm{~d}$ & $28 \mathrm{~d}$ & $42 \mathrm{~d}$ \\
\hline Maize & $0.79 \mathrm{~b}$ & $0.83 \mathrm{a}$ & $0.83 \mathrm{a}$ \\
Sorghum & $0.79 \mathrm{ab}$ & $0.77 \mathrm{~b}$ & $0.81 \mathrm{a}$ \\
Wheat & $0.78 \mathrm{a}$ & $0.72 \mathrm{~b}$ & $0.72 \mathrm{~b}$ \\
Millmix & $0.61 \mathrm{~b}$ & $0.62 \mathrm{~b}$ & $0.74 \mathrm{a}$ \\
Soyabean meal & $0.85 \mathrm{~b}$ & $0.87 \mathrm{a}$ & 0.010 \\
Canola meal & $0.80 \mathrm{~b}$ & $0.81 \mathrm{a}$ & 0.007 \\
Cottonseed meal & 0.69 & 0.70 & 0.006 \\
Meat \& bone meal & $0.77 \mathrm{~b}$ & $0.80 \mathrm{a}$ & 0.004 \\
\hline
\end{tabular}

${ }^{\mathrm{abc}}$ Means in a row bearing different superscripts are significantly different $(\mathrm{p}<0.5)$.

\section{Additivity of values}

Additivity of digestible amino acids, determined in single feedstuffs, is a crucial consideration in the formulation of complete diets. Studies by Angkanaporn et al. (1996) and Bryden \& Li (2003) found that digestible amino acid supply in a complete diet can be predicted from apparent amino acid digestibilities determined for individual feed ingredients (Table 6).

Investigations with a wide variety of ingredients may be warranted to determine the possibility of associative effects between feedstuffs especially those containing anti-nutritional factors.

\section{Australian ileal digestibility data set}

In Australia, a wide range of feedstuffs are used in poultry diets. Over a number of years, we have conducted a series of ileal digestibility bioassays with broiler chickens to estimate the amino acid availability of a range of feed ingredients and provide data to the industry that will improve the precision of feed formulation. The procedures followed for the determination of digestibility of individual feed samples is outlined below. The results of these studies have been compiled (Bryden et al., 2009a) and include our previous studies at the University of Sydney (Ravindran et al., 1998a) and our recent research at the University of Queensland.

Different assay diets were used for cereal grains and protein meals so that the test feedstuff was the only source of protein in the assay diet (Bryden et al., 2009a). Each assay diet was offered ad libitum to three pens of male broilers from 35 to 42 days of age. At the end of the bioassay, all birds in a pen were euthanased with an intracardial injection of a barbiturate and the contents of the lower half of the ileum (ie a few cms from the ileocaecal junction to midway between the ileocaecal junction and the vitelline diverticulum) were collected and pooled.

Amino acid concentrations in samples of assay diets and ileal digesta were determined using cation-exchange column chromatographic procedures with post-column derivatisation and fluorimetric detection of amino acids using 0 -phthaldialdehyde (Li et al., 2006). Tryptophan was determined separately after alkaline hydrolysis with $\mathrm{NaOH}$ followed by isocratic ion-exchange chromatography with $O$-phthalaldehyde derivatisation followed by fluorescence detection (Ravindran \& Bryden, 2005). Ileal amino acid digestibility coefficients were calculated using acid insoluble ash (AIA) as an indigestible dietary marker. Digestible amino acid concentrations were calculated from total concentrations and respective digestibility coefficients.

The apparent ileal amino acid digestibility values of 137 samples, representing 28 feed ingredients have been determined (Table 7). Tryptophan data for selective feed ingredients are also included. In addition to individual sample values, a summary of data for total amino acid concentrations, apparent ileal amino acid digestibility

Table 6 - The predicted and determined apparent ileal digestibility coefficients for selected amino acids (Bryden \& Li, 2003)

\begin{tabular}{lccc}
\hline Amino acid & Predicted (Diet 1) & Determined (Diet 1) & Predicted (Diet 2) \\
\hline Threonine & 0.725 & 0.711 & 0.741 \\
Alanine & 0.798 & 0.770 & 0.781 \\
Valine & 0.752 & 0.715 & 0.747 \\
Isoleucine & 0.757 & 0.718 & 0.755 \\
Leucine & 0.792 & 0.773 & 0.796 \\
Phenylalanine & 0.789 & 0.775 & 0.795 \\
Lysine & 0.786 & 0.773 & 0.783 \\
\hline
\end{tabular}

Note: Diets 1 and 2 had identical dietary composition using the same batch of ingredients but Diet 1 was formulated on the basis of published digestible amino acid values (Ravindran et al., 1998a) and Diet 2 was formulated on the basis of determined amino acid digestibility of the ingredients. 
Table 7 - Summary of feedstuffs assayed for apparent ileal amino acid digestibility by Bryden et al ( 2009a) using broiler chickens

\begin{tabular}{lc}
\hline Feedstuff & Number of samples \\
\hline Cereals and cereal by-products & 59 \\
Oilseed meals & 43 \\
Grain legumes & 11 \\
Animal protein meals & 17 \\
Miscellaneous & 7 \\
\hline
\end{tabular}

coefficients and digestible amino acid concentrations in feed ingredients are presented. Sufficient data was collected for major feed ingredients to permit calculation of linear regression equations describing total and apparent ileal digestible amino acid content as a function of total and apparent ileal digestible crude protein content.

\section{Conclusions}

There has been a shift away from the use of total to digestible amino acids for poultry feed formulation. Initial emphasis was on the use of adult cockerels in digestibility bioassays but this has gradually changed to use of broilers for the determination of ileal digestibility. However, there is a need to establish an internationally agreed protocol for ileal digestibility determination and also agreement on the endogenous amino acid values to be used for converting apparent ileal digestibility values to standardized values. Both aspects require further research as does the additivity of values especially when low quality protein feedstuffs are used in poultry diets. Further refinement of ileal digestibility data sets through research and application will provide economic and sustainability advantages for poultry production with the increasing global demand for meat.

\section{References}

AMERAH, A.M.; RAVINDRAN, V.; LENTLE, R.G. et al. Feed particle size: implications on the digestion and performance in poultry. World's Poultry Science Journal, v.63, p 439-451, 2007.

ANGKANAPORN, K., CHOCT, M., BRYDEN, W.L. et al. Effects of wheat pentosans on endogenous amino acid losses in chickens. Journal of the Science Food and Agriculture, v.66, p.399404, 1994.

ANGKANAPORN, K.; RAVINDRAN, V.; BRYDEN, W.L. Additivity of apparent and true ileal amino acid digestibilities in soybean meal, sunflower meal and meat and bone meal for broilers, Poultry Science, v.75, p.1098-1103, 1996.

BATAL, A.B.; PARSONS, C.M. Effects of age on nutrient digestibility in chicks fed different diets. Poultry Science, v.81, p.400-407, 2002.

BOISEN, S. A new protein evaluation system for pig feeds and its practical application. Acta Agriculturae Scandinavica. Section A, Animal Science, v.48, p.1-11, 1998.
BRYDEN, W.L. Antinutritive factors in protein metabolism. In: NUNES, A.F.; PORTUGAL, A.V.; COSTA, J.P. et al. (Eds.) Protein metabolism and nutrition. Vale de Santarem, Portugal: Estacao Zootecnica Nacional, 1996. p.517-518, 1996.

BRYDEN, W.L.; ANGKANAPORN, K.; RAVINDRAN, V. et al. Use of homoarginine technique to determine endogenous amino acid losses in poultry and pigs. In: NUNES, A.F.; PORTUGAL, A.V.; COSTA, J.P. et al. (Eds.) Protein metabolism and nutrition. Vale de Santarem, Portugal: Estacao Zootecnica Nacional, 1996. p.319-323.

BRYDEN, W.L.; LI, X. Utilisation of digestible amino acids by broilers. A report for the rural industries research and development corporation. 2002. 46p.

BRYDEN, W.L.; LI, X. Prediction of amino acid digestibility of complete broiler diets. Proceedings of the Australian Poultry Science Symposium, v.15, p.67, 2003.

BRYDEN, W.L.; LI, X.; RAVINDRAN, G. et al. Ileal digestible amino acid values in feedstuffs for poultry. A report for the rural industries research and development corporation. 2009a. 85p.

BRYDEN, W.L.; SELLE, P.H.; CADOGAN, D.J. et al. A review of the nutritive value of sorghum for broilers. A report for the rural industries research and development corporation. 2009b. 68p.

BRYDEN, W.L.; SELLE, P.H.; RAVINDRAN, V. et al. Phytate: an anti-nutrient factor in animal diets. In: PANTER, K.E.; WIEREnGA, T.L.; PFISTER, J.A. (Eds.) Poisonous plants: global research and solutions. Wallingford: CABI Publishing, 2007. p.279-284

BRYDEN, W.L.; RAVINDRAN, V. Enzyme combinations and nutrient digestibility of wheat for broiler chickens. Proceedings of the Australian Poultry Science Symposium, v.11, p.170, 1999.

COWIESON, A.J.; BEDFORD, M.R. The effect of phytase and carbohydrase on ileal amino acid digestibility in monogastric diets: complimentary mode of action? World's Poultry Science Journal, v.65, p.609-624, 2009.

COWIESON, A.J.; BEDFORD, M.R.; SELLE, P.H. et al. Phytate and microbial phytase: implications for endogenous nitrogen losses and nutrient availability. World's Poultry Science Journal, v.65, p.401-417, 2009.

DALE, N. Variation in feed ingredient quality: oilseed meals, Animal Feed Science and Technology, v.59, p.129-135, 1996.

DOUGLAS, M.W.; PARSONS, C.M. Dietary formulation with rendered spent hen meals on a total amino acid versus a digestible amino acid basis, Poultry Science, v.78, p.556-560, 1999.

FERNANDEZ, S.R.; PARSONS, C.M. Bioavailability of the digestible lysine and valine in cottonseed and soybean meals for chicks. Poultry Science, v.75, p.216-223, 1996.

FRIEDMAN, M. Food browning and its prevention: an overview, Journal of Agricultural and Food Chemistry, v.44, p.631653, 1996.

GARCIA, A.R.; BATAL, A.B.; DALE, N.M. A comparison of methods to determine amino acid digestibility of feed ingredients for chickens, Poultry Science, v.86, p.94-101, 2007.

HAMILTON, R.M.G.; PROUDFOOT, F.G. Ingredient particle size and feed texture: effect on performance of broiler chickens, Animal Feed Science and Technology, v.51, p.203-210, 1995.

HEW, L.I.; RAVINDRAN, V.; MOLLAH, Y. et al. Influence of exogenous xylanase supplementation on apparent metabolisable energy and amino acid digestibility in wheat for broiler chickens, Animal Feed Science and Technology, v.75, p.83-92, 1998.

HEW, L.I.; RAVINDRAN, V.; RAVINDRAN, G. et al. The apparent metabolisable energy and emino acid digestibility of wheat, triticale and wheat middlings for broiler chickens as affected by exogenous xylanase supplementation, Journal of the Science of Food and Agriculture, v.79, p.1727-1732. 
HUANG, K.H.; LI, X.; RAVINDRAN, V. et al. Comparison of apparent ileal amino acid digestibility of feed ingredients measured with broilers, layers and roosters. Poultry Science, v.85, p.625-632, 2006.

HUANG, K.H.; RAVINDRAN, V.; LI, X. et al. Influence of age on the apparent ileal digestibility of feed ingredients for broiler chickens. British Poultry Science, v.46, p.236-245, 2005.

HUANG, K.H.; RAVINDRAN, V.; LI, X. et al. Apparent ileal digestibility of amino acids in feed ingredients determined with broilers and layers. Journal of the Science of Food and Agriculture, v. 87, p, 47-53, 2007.

HUGHES, R.J.; CHOCT, M. Chemical and physical characteristics of grains related to variability in energy and amino acid availability in poultry. Australian Journal of Agricultural Research, v.50, p.689-701, 1999.

LEMME, A.; RAVINDRAN, V.; BRYDEN, W.L. Ileal digestibility of amino acids in feed ingredients for broilers. World's Poultry Science Journal, v.60, p.421-435, 2004.

LI, X.; KURKO, K.V.; HUANG, K. et al. Performance of broilers fed diets formulated using total or digestible amino acid values, Proceedings of the Australian Poultry Science Symposium, v.14, p.179, 2002a.

LI, X.; MOLLET, P.; HUANG, K. et al. Processing and the protein quality of canola meal. In: WORLD POULTRY SCIENCE ASSOCIATION ASIAN PACIFIC FEDERATION CONFERENCE, 7., AUSTRALIAN POULTRY AND FEED CONVENTION, 12., 2002. Proceedings... s.l.: 2002b. p. 240.

LI, X.; MOLLET, P.; HUANG, K. et al. Inclusion level of cottonseed meal in broiler diets. In: WORLD POULTRY SCIENCE ASSOCIATION ASIAN PACIFIC FEDERATION CONFERENCE, 7., AUSTRALIAN POULTRY AND FEED CONVENTION, 12., 2002. Proceedings... s.l.: 2002c. p.256.

LI, X., HIGGINS, T.J.V.; BRYDEN, W.L. Biological reponse of broiler chickens fed peas (Pisum sativum L.) expressing the bean (Phaseolus vulgaris L.) á-amylase inhibitor transgene, Journal of the Science of Food and Agriculture, v.86, p.1900-1907, 2006.

McNAB, J.M. Amino acid digestibility and availability studies with poultry. In: $\mathrm{D}^{\prime}$ MELLO, J.P.F. (Ed.) Amino acids in farm animal nutrition. Wallingford: CAB International, 1994. p.63-98.

MOUGHAN, P.J.; DARRAGH, A.J.; SMITH, W.C. et al. Perchloric and trichloaacetic acids as precipitants of protein in endogenous ileal digesta from the rat, Journal of the Science of Food and Agriculture, v.52, p.13-21, 1990.

PARSONS, C.M. Digestibility and bioavailability of protein and amino acids. In: MCNAB, J.M.; BOOMAN, K.N. (Eds.) Poultry feedstuffs: supply, composition and nutritive value. Wallingford: CABI Publishing, 2002. p.115-135.

RADEMACHER, M.; SAUER, W.C.; JANSMAN, A.J.M. Standardised ileal digestibility of amino acids in pigs. Hanua: Feed Additives Division, Degussa-Huls AG, 1999. 46p.

RAVINDRAN, V.; ADEOLA, O.; RODEHUTSCORD, M. et al. Ileal amino acid digestibility assays in poultry: case for a universal approach. In: EUROPEAN SYMPOSIUM OF POULTRY NUtrition, 16., 2009, Edinburgh, UK. Proceedings... Edinburgh: 2009. p.192.

RAVINDRAN, G.; BRYDEN, W.L. Tryptophan determination in proteins and feedstuffs by ion exchange chromatography. Food Chemistry, v.89, p.309-314, 2005.

RAVINDRAN, V.; BRYDEN, W.L. Amino acid availability in poultry - in vitro and in vivo measurement. Australian Journal of Agricultural Research, v.50, p.889-908, 1999a.

RAVINDRAN, V.; BRYDEN, W.L. Evaluation of broiler diets containing graded levels of cottonseed meal and formulated on the basis of total or digestible amino acids, Proceedings of the Australian Poultry Science Symposium, v.11, p,168, 1999b.

RAVINDRAN, V.; BRYDEN, W.L. Evaluation of meat and bone meal in broiler starter diets formulated on the basis of total or digestible amino acids. Proceedings of the Australian Poultry Science Symposium, v.11, p.169, 1999c.

RAVINDRAN, V.; CABAHUG, S.; RAVINDRAN, G. et al. Response of broiler chickens to microbial phytase supplementation as influenced by dietary phytic acid and non-phytate phosphorus levels. II. Effects on nutrient digestibility and retention. British Poultry Science, v.41, p.193-200, 2000.

RAVINDRAN, V.; HEW, L.I.; RAVINDRAN, G. et al. A comparison of ileal digesta and excreta analysis for the determination of amino acid digestibility in feed ingredients for poultry. British Poultry Science, v.40, p.266-274, 1999.

RAVINDRAN, V.; CADOGAN, D.J.; CABAHUG, S. et al. Effects of phytic acid on the performance of poultry and swine, In: COELho, M.B.; KORNEGAY, E.T. (Eds.) Phytase in animal nutrition and waste management. 2.ed.rev. Parsippany, New Jersey: BASF Corporation, 1999b. (BASF Monograph Series). p.93-99.

RAVINDRAN, V.; HENDRIKS, W.H. Endogenous amino acid flows at the terminal ileum of broilers, layers and adult roosters. Animal Science, v.79, p.265-271, 2004.

RAVINDRAN, V.; HENDRIKS, W.H.; CAMDEN, B.J. et al. Amino acid digestibility of meat and bone meal for broiler chickens, Australian Journal of Agricultural Research, v.53, p.12571264, 2002.

RAVINDRAN, V.; HEW, L.I.; BRYDEN, W.L. Digestible amino acids in poultry feedstuffs. A Report for the Rural Industries Research and Development Corporation, 1998a. 54p.

RAVINDRAN, V.; HEW, L.I.; BRYDEN, W.L. Broiler feed formulations with canola meal based on total or digestible amino acids. Proceedings of the Australian Poultry Science Symposium, v.10, p.209, 1998b.

RAVINDRAN, V.; HEW, L.I.; RAVINDRAN, G. et al. Endogenous amino acid flow in the avian ileum: quantification using three methods. British Journal of Nutrition, v.92, p.217-223, 2004.

RAVINDRAN, V.; SELLE, P.H.; RAVINDRAN, G. et al. Microbial phytase improves performance, apparent metabolizable energy and ileal amino acid digestibility of broilers fed a lysine-deficient diet. Poultry Science, v.80, p.338-344, 2001.

ROOS, N.; PFEUFFER, M.; HAGEMEISTER, H. Labelling with ${ }^{15} \mathrm{~N}$ as compared with homoarginine suggests a lower prececal digestibility of casein in pigs. Journal of Nutrition, v.124, p.2404-2409, 1994.

ROSTAGNO, H.S.; PUPA, J.M.R.; PACK, M. Diet formulation for broilers based on total versus digestible amino acids. Journal of Applied Poultry Research, v.4, p.293-299, 1995.

SAUER, W.C.; DUGAN, M.; DE LANGE, C.F.K. et al. Considerations in methodology for the determination of amino acid digestibilities in feedstuffs for pigs. In: FRIEDMAN, M. (Ed.) Absorption and utilisation of amino acids. Boca Raton: CRC Press, 1989. p.217-230.

SELLE, P.H.; CADOGAN, D.J.; LI, X. et al. Implications of sorghum in the nutrition of broiler chickens. Animal Feed Science and Technology, v.156, p.57-74, 2010.

SELLE, P.H.; RAVINDRAN, V. Microbial phytase in poultry nutrition, Animal Feed Science and Technology, v.135, p.1-41, 2007.

SELLE, P.H.; RAVINDRAN, V.; BRYDEN, W.L. Influence of dietary phytate and exogenous phytase on amino acid digestibility in poultry: a review. Journal of Poultry Science, v.43, p.89-103, 2006.

SELLE, P.H.; RAVINDRAN, V.; CALDWELL, R.A. et al. Phytate and phytase: consequences for protein utilisation. Nutrition Research Reviews, v.13, p.255-278, 2000

SELLE, P.H.; RAVINDRAN, V.; KIES, A.K. et al. Phytase supplementation of a lysine deficient broiler diet. I. Effects of growth performance and toe ash contents. Proceedings of the Australian Poultry Science Symposium, v.12, p.207, 2000.

SELLE, P.H.; RAVINDRAN, V.; RAVINDRAN, G. et al. Influence of phytase and xylanase supplementation on growth 
performance and nutrient utilisation of broilers offered wheatbased diets. Asian-Australasian Journal of Animal Science, v.16, p.394-402, 2003a.

SELLE, P.H.; RAVINDRAN, V.; PITTOLO, P.H. et al. Effects of phytase supplementation of diets with two tiers of nutrient specifications on growth performance and protein efficiency ratios of broiler chickens. Asian-Australasian Journal of Animal Science, v.16, p.1158-1164, 2003b.

SIBBALD, I.R. Estimation of bioavailable amino acids in feedingstuffs for poultry and pigs: a review with emphasis on balance experiments. Canadian Journal of Animal Science, v.67, p.221-300. 1987.

SIRIWAN, P.; BRYDEN, W.L.; ANNISON, E.F. Use of guanidinated dietary protein to measure losses of endogenous amino acid in poultry. British Journal of Nutrition, v.71, p.515-529, 1994.
STEIN, H.H.; SEVE, B.; FULLER, M. et al. Invited review: amino acid bioavailability and digestibility in pig feed ingredients: terminology and application. Journal of Animal Science, v.85, p.172-180, 2007.

SKURRAY, G.R. The nutritional evaluation of meat meals for poultry. World's Poultry Science Journal, v.30, p.129136, 1974.

SULTAN, A.; LI, X.; ZHANG, D. et al. Dietary enzymes alter sorghum protein digestibility and AME content. Proceedings of the Australian Poultry Science Symposium, v.21, p.94, 2010.

WALLIS, I.R.; BALNAVE, D. A comparison of amino acid digestibility bioassays for broilers. British Poultry Science, v.25, p.389-399, 1984. 